\title{
ABSURDITAS DALAM NASKAH DRAMA JALAN LURUS KARANGAN WISRAN HADI DAN IMPLIKASINYA DALAM PEMBELAJARAN SASTRA DI SMA
}

\author{
Rais \\ Sekolah Victory Plus \\ E-mail: raisdja@gmail.com
}

\begin{abstract}
ABSTRAK
Penelitian ini bertujuan untuk mengetahui absurditas dalam naskah drama Jalan Lurus karangan Wisran Hadi. Penelitian ini menggunakan metode deskriptif kualitatif. Teori absurditas yang digunakan dalam penelitian ini berdasarkan pendapat Albert Camus tentang tema-tema dalam absurditas. Hasil penelitian ini menunjukkan drama Jalan Lurus karangan Wisran Hadi merupakan bentuk drama absurd. Absurditas tersebut ialah makna hidup, keterasingan, bunuh diri, harapan, dan pemberontakan. Tema makna hidup paling sering disampaikan dalam naskah drama Jalan Lurus. Sementara itu, tema bunuh diri dan pemberontakan dalam naskah drama Jalan Lurus menjadi tema yang paling sedikit disampaikan. Implikasinya dalam pembelajaran sastra di SMA, guru dapat menggunakan drama ini sebagai alternatif bahan ajar. Namun, hal tersebut perlu disesuaikan dengan perkembangan siswa. Dalam pembelajaran, pembahasan meliputi karya sastra inkonvensional, jenis drama absurd, ciri-ciri drama absurd, dan aspek absurditas.
\end{abstract}

Kata kunci: absurditas, drama, Jalan Lurus, Albert Camus, pembelajaran sastra

\section{THE ABSURDITY IN JALAN LURUS BY WISRAN HADI AND ITS IMPLICATIONS IN LITERATURE LEARNING IN SENIOR HIGH SCHOOL}

\begin{abstract}
This research aims to find out the absurdity in Jalan Lurus drama script by Wisran Hadi. This study uses qualitative descriptive method. The absurdity theory used in this study is based on Albert Camus's opinion on the themes of absurdity. The result of this research shows Jalan Lurus by Wisran Hadi is a form of absurd drama. The absurdity is the meaning of life, alienation, suicide, hope, and rebellion. The theme of life is most often presented in this drama. Meanwhile, the theme of suicide and rebellion in this drama became the least talked theme. Implications in literary learning in high school, teachers can use this drama as an alternative teaching material. However, it needs to be accomodated to the student's development. In learning, the discussion includes unconventional literary works, absurd drama types, absurd drama characteristic, and absurdity aspects.
\end{abstract}

Keywords: absurdity, drama, Jalan Lurus, Albert Camus, literature learning 


\section{PENDAHULUAN}

Dalam sejarah teater di Indonesia, tahun 1970-an merupakan tahun-tahun penting. JakobSumardjo menyebut periode 1970-1980-an sebagai zaman emas kedua teater modern Indonesia. Disebut zaman emas kedua karena pada tahun-tahun tersebut teater Indonesia bangkit kembali setelah beberapa waktu sempat terganggu oleh prahara politik pada 1965. Semakin surutnya ketegangan politik dan disusul berdirinya Taman Ismail Marzuki dengan Dewan Kesenian Jakarta menjadi faktor yang memungkinkan bangkitnya penulisan lakon dan kegiatan pementasan teater. Kebangkitan itu dapat terlihat dari munculnya lakon-lakon dan pementasan yang eksperimental dan nonkonvensional.

Fakta lain yang juga menarik bahwa sejumlah drama pada waktu itu mengingatkan kita pada ciri drama absurd, satu jenis drama yang berkembang di Barat sejak 1940-an setelah Perang Dunia II. Ada kemungkinan para penulis lakon dan aktivis teater pada waktu itu terpengaruh oleh masuknya drama absurd ke Indonesia. Ciri lain yang juga menonjol yakni hadir dan kentalnya unsur humor dalam lakon-lakon yang ditulis pada waktu itu yang mengingatkan pada ciri teater rakyat Indonesia (Wasono, 2007).

Kecenderungan Wisran Hadi yang mendekonstruksi dan bereksperimen dengan randai dan kaba menjadi naskah drama, naskah dramanya yang memberikan gagasan dan bentuk baru dalam melihat tradisi, posisinya yang digolongkan dalam jalur kedua dalam teater modern, naskah dramanya yang memaksimalkan dan mengeksplorasi kata, bentuk naskah dramanya yang lepas dari konvensi yang ada atau inkonvensional, dan perkembangan penulisan dramanya yang berlangsung pada zaman emas kedua teater modern Indonesia semakin memperlihatkan adanya gaya absurd dalam karya-karyanya. 
Selain itu, Wisran Hadi pernah mengikuti Internasional Writing Program di LowaUniversity, USA pada tahun 1997, Observasi teater modern Amerika di USA pada 1978, dan mengikuti observasi teater modern Amerika dan Jepang pada 1986 (Yudiaryani, 2002).

Salah satu karyanya yaitu Jalan Lurus menyajikan sesuatu yang berbeda dari karyanya kebanyakan. Jalan Lurus ditulis Wisran Hadi di Padang pada Januari 1986. Naskah drama Jalan Lurus mendapatkan Hadiah Sastra dari Pusat Bahasa pada tahun 1991. Selain itu, Jalan Lurus menjadi naskah drama terbaik pada Pertemuan Sastrawan Nusantara pada 1997. Drama Jalan Lurus juga pernah di pentaskan di Taman Ismail Marzuki pada 17-19 Desember 1993 produksi Bumi Teater dengan disutradai oleh Wisran Hadi.

Konsep absurd dikenalkan oleh Albert Camus dalam esainya yang berjudul Mite Sisifus yang ditulis pada tahun 1941 dan diterbitkan pada tahun 1942. Camus bukanlah penemu absurditas. Intuisi mengenai absurd sudah ada sejak sebelum perang dunia I yang dikenalkan melalui tokoh eksistensialisme Nietzsche, Kierkegaard, Husserl, dan Jaspers. Albert Camus menggunakan cara berbeda dengan pendahulunya. Camus menghubungkan mata rantai eksistensialisme dengan absurditas. Mite Sisifus tidak menganalisis para pendahulunya, ia menggambarkan letak tonggak-tonggak dalam alam pikiran mereka.

Inti cerita Mite Sisifus diambil dari mitologi Yunani Kuno. Dalam cerita itu dikisahkan bahwa Sisifus dihukum para dewa. Hukuman yang harus dilakukan Sisifus ialah mengangkut batu yang berakhir di puncak, batu itu menggelinding kembali, kemudian Sisifus mengangkut batu itu kembali ke puncak. Hukuman itu terus berulang 
dilakukan oleh Sisifus. Hukuman Sisifus dimaknai oleh Camus sebagai amsal hidup manusia.

Dengan melihat absurditas dalam naskah drama Jalan Lurus karangan Wisran Hadi, diharapkan dapat memberikan gambaran jelas bagaimana absurd ditampilkan dalam sebuah karya sastra khususnya drama dan dapat memahami jenis-jenis drama yang ada di Indonesia. Penelitian ini juga diharapkan dapat memberikan sumbangsih dalam pengembangan bahan ajar bahasa dan sastra Indonesia serta memberikan pandangan dunia baru bagi para pembaca dan penikmat karya sastra untuk lebih memaknai hidup.

Dalam refleksi filosofis beberapa filsuf eksistensialis, absurd mengacu pada kehidupan yang tidak berarti, tidak konsisten, dan tidak mempunyai struktur, namun absurd tidak begitu saja dapat disamakan dengan tidak bermakna atau bernilai. Absurd tidak sama dengan omong kosong. Absurd mempunyai nilai, atau bermakna, tetapi tidak benar atau salah. Dalam bahasa Inggris kata nonsense sering diartikan dengan absurditas (Bagus, 2000).

Secara leksikal 'absurd' berarti ketidakselarasan, yang menunjuk keadaan tidak harmonis, Secara etimologis kata 'absurditas' diturunkan dari bahasa latin absurdus yang terbentuk dari kata $a b$ berarti 'tidak' dan surdus berarti 'dengar'. Jadi, absurd berarti tidak enak didengar, tuli, dan tidak berperasaan. Absurd juga sering diartikan tidak masuk akal atau tidak logis (Soemanto, 2007).

Selaras dengan Bagus, Rowlands (2004) mengatakan bahwa absurditas merupakan istilah yang disukai filosof eksistensialis Prancis seperti Sastre dan Camus, 
dan sebagaimana konsep lazim absurditas, "absurd" tidak sekadar berarti "bodoh" atau "konyol".

Absurditas merupakan ciri utama keberadaan manusia yang muncul dalam gerakan filsafat yang dikenal dengan sebagai eksistensialisme. Absurditas muncul karena adanya benturan antara pandangan dari dalam tentang diri sendiri dan pandangan dari luar. Benturan ini juga yang merupakan gejala dari masalah-masalah filsafat yang mendalam, sehingga absurditas dapat dianggap berada dalam jantung filsafat, sebagaimana keberadaan manusia.

Landasan uraian absurditas menurut pandangan Camus diawali dengan pernyataan bahwa absurditas dapat memaksa manusia untuk menghindarinya melalui harapan atau bunuh diri. Oleh karena itu, Camus menilai persoalan tentang kematian, khususnya mengenai bunuh diri dikarenakan perasaan bahwa hidup tidak layak untuk dijalani. Jadi, Camus mempersoalkan tentang makna hidup yang menyebabkan seseorang mengambil suatu keputusan pada hidup (Camus, 1999).

Dari pertanyaan-pertanyaan Camus tersebut, yang harus dapat dijelaskan, tergambar adanya hubungan antara makna hidup, harapan, dan bunuh diri yang sekaligus menjadi tiga aspek utama mengenai absurditas. Manusia hidup untuk mempunyai makna, makna hidup dimiliki manusia selama manusia mempunyai harapan, hal itu juga yang menjadi pilihan bagi manusia. Jika manusia tidak mempunyai harapan yang berarti tidak memiliki makna hidup, pilihannya ialah melanjutkan hidup dengan harapan atau mengakhiri hidup dengan bunuh diri.

Selain ketiga aspek tersebut, Camus menerangkan keterasingan sebagai salah satu bentuk absurditas seperti dalam eksistensialisme, kesadaran manusia akan dirinya yang merasa terasing dari dunianya. Keterasingan yang dimaksud di atas ialah suatu 
perceraian manusia dengan hidupnya. Perceraian tersebut ditegaskan menjadi suatu perasaan absurditas yang sesungguhnya. Keterasingan juga berkaitan erat dengan bunuh diri dan hasrat akan ketiadaan makna hidup.

Dari pernyataan tersebut, Camus menolak tindakan bunuh diri sebagai jalan keluar dari absurditas, yang ditawarkan Camus bukanlah bunuh diri meskipun secara sadar kematianlah jalan keluarnya. Camus mengajak untuk melakukan penolakan terhadap yang absurd dengan melakukan pemberontakan. Menurut Camus, pemberontakan itu memberikan nilai pada hidup. Itu artinya ada harapan untuk memberikan makna pada hidup melalui pemberontakan.

Akibat dari pemberontakan itu ialah bahwa manusia mempunyai satu pengertian baru mengenai kebebasan. Manusia yang tidak mempunyai ukuran nilai, maka ia tidak mempunyai pilihan lain. Ia memiliki kebebasan penuh atas hidupnya. Pemikiran tentang kebebasan sejalan dengan konsep pemberontakan. Dengan demikian, kesadaran manusia akan hak-haknya yang membuat manusia berpikir untuk melakukan pemberontakan, sehingga manusia dapat menjalani hidup sesuai dengan keinginannya sendiri.

Berdasarkan kajian historis yang dilakukan oleh Esslin, dapatlah diketahui bahwa teater absurd sebenarnya kembali pada tradisi lampau, bahkan arkais. Kebaruannya hanya terletak pada kombinasi baru dari tradisi-tradisi yang mendahuluinya itu.Tradisi zaman lampau yang oleh teater absurd ditampilkan dalam kombinasi yang berbeda, dalam arti baru dan masing-masing mempunyai kekhasannya sendiri. Dengan begitu Esslin menarik kesimpulan bahwa ciri-ciri drama absurd sebagai berikut: (1) teater murni; suatu sajian abstrak seperti dalam sirkus atau reveu (di Indonesia, mungkin mirip dengan Teater Mini Kata, pendek dan ringkas); juga mirip 
dengan para jugglers, yakni akrobat terampil yang bermain-main dengan beberapa bola diumbul-umbulkan, pisau, dan lain-lain; para akrobat, petarung banteng, pemain pantomim sebangsa jemek (2) Badut-badutan, tokoh-tokoh konyol seperti fooldalam lakon King Lear atau Limbuk-Cangik dalam wayang kulit; atau adegan gila-gilaan (3) Permainan kata-kata yang tidak ada artinya: verbal nonsense; seperti pada dagelan Basiyo, tetapi sangat menggelikan. (4) Sastra mimpi dan fantasi yang sering berisi petuah-petuah atau anjuran alegoris, misalnya cerita dalam buku serial Harry Potters (Soemanto, 2007).

Perumusan ciri tersebut berdasarkan pendapat Goenawan Muhammad dan Sapardi Djoko Damono. Secara ringkas ciri-ciri drama absurd pada tahun 1970-an sebagai berikut: (1) ambisi lakon mutakhir pada umumnya ialah ke arah teater puisi yang utuh. Naskahnya hanya berupa kerangka dari suatu dan bukan cerita tentang situasi, (2) adanya unsur humor yang bersifat "kecerdasan" atau wityang dilandasi hasil proses pemikiran intelektual, (3) masuknya unsur teater rakyat Indonesia yang mencampuradukkan suasana getir, pahit, duka dengan tawa, lelucon, dan farce. (4) mengambil latar belakang kehidupan kaum gelandangan atau kaum underdog yang diperlakukan sebagai seorang intelektual, (5) sifat simbolik dari keseluruhan pentas, (6) yang penting adalah penciptaan suasana puitis di pentas, dan itu semua berbau tangan sutradara (Wasono, 2007).

\section{METODE}

Penelitian ini menggunakan metode deskriptif kualitatif dengan teknik analisis isi. Naskah drama sebagai objek ditelaah dengan teori absurditas untuk menemukan aspek-aspek absurditas berdasarkan teori Albert Camus pada naskah drama Jalan Lurus 
karangan Wisran Hadi. Analisis dalam penelitian ini didasarkan pada teori absurd yang dijabarkan oleh Albert Camus, meliputi: makna hidup, keterasingan, bunuh diri, harapan, dan pemberontakan.

Makna hidup, merupakan dasar dari seseorang ketika merasakan mengenai kelayakan hidup dan mengalami sesuatu yang absurd. Ditandai dengan adanya tindakan berupa pertentangan antara manusia dengan lingkungan sekitarnya. Keterasingan, merupakan suatu perasaan manusia yang kehilangan keyakinannya terhadap hidup dan membuat dirinya berjarak dengan kehidupan nyata. Perasaan terasing ada ketika manusia berada dalam satu lingkungan tetapi dia mementingkan dirinya sendiri. Bunuh diri, merupakan pilihan seorang manusia saat merasakan hidup tidak lagi mempunyai makna dan merupakan pilihan untuk keluar dari sesuatu yang absurd tersebut. Bunuh diri dalam hal ini berupa pembunuhan fisik dan filosofi. Harapan, merupakan pilihan manusia untuk bebas dari sesuatu yang absurd. Namun, harapan dapat pula mengkhianati manusia yang memilih tindakan tersebut. Di sini terdapat dua hasil dari tindakan memilih hidup dengan harapan sebagai jalan keluar dari yang absurd, yakni harapan tersebut terwujud sesuai kehendak seseorang atau tidak. Pemberontakan, merupakan jalan keluar dari absurditas. Manusia sadar akan hak-haknya dan akan kebenaran yang ada. Artinya, manusia memiliki kebebasan untuk berkehendak menjalani hidup sesuai dengan keinginannya sendiri dengan melawan sesuatu yang menghalanginya memberikan makna pada hidup.

\section{HASIL DAN PEMBAHASAN}

Berdasarkan analisis teks terhadap naskah drama Jalan Lurus karangan Wisran Hadi, dapat dipahami bahwa naskah tersebut mengusungkan sebuah bentuk drama 
absurd. Bentuk drama absurd ini disajikan dalam segi struktur dan tekstur yang memperlihatkan sebagai ciri drama absurd. Bentuk drama absurd Jalan Lurus ini masih mengacu pada naskah-naskah drama yang lahir pada tahun 70-an, yaitu berupa naskahnaskah drama eksperimental dan memiliki ciri keindonesiaannya.

Dalam segi tekstur bentuk drama absurd, Jalan Lurus memperlihatkan ketiadaan alur di dalam cerita. Jalan Lurus menolak suatu peristiwa yang hanya berjalan secara runtut dari A ke Z. Bentuk penolakan tersebut disajikan dengan alur yang melingkar. Alur melingkar tersebut membawa pembaca akan cerita yang tidak pernah berakhir. Sebagai bentuk cerita yang anti alur, Jalan Lurus menampilkan berbagai episodeepisode kehidupan manusia. Dalam setiap episode sering kali kejadian di dalamnya menyajikan bentuk pengulangan. Pengulangan itu pun yang akhirnya tidak pernah menyelesaikan masalah dalam setiap adegan yang diperankan. Bentuk pengulangan ini terlihat dari peran tokoh Lakon yang sering berubah. Selain itu, tindakan para lelaki yang memanjat tiang merupakan bentuk pengulangan peristiwa yang selalu dilakukan tanpa mereka sadari. Hal ini pula yang mencirikan Jalan Lurus memiliki pemahaman yang sama dengan absurditas Albert Camus. Esai Mite Sisifus menyajikan sebuah bentuk pengulangan atau rutinitas yang dilakukan manusia yang sama halnya dalam Jalan Lurus dilakukan oleh serombongan lelaki dalam memanjat tiang.

Struktur teks Jalan Lurus juga menunjukkan tokoh-tokoh yang absurd. Keabsurdan tokoh-tokoh ini dapat dilihat secara sepintas dengan tidak adanya nama yang mereka miliki. Teks menunjukkan bahwa mereka hanya serombongan lelaki. Selain itu, tokoh-tokoh dalam Jalan Lurus merupakan tokoh-tokoh yang dapat berganti peran, ini mencirikan sebuah bentuk drama absurd yang khas bahwa apa saja dapat terjadi. Hal ini juga yang mencirikan bahwa tokoh-tokoh tersebut bukanlah hanya dapat 
dianggap sebagai manusia, tetapi bisa saja tokoh-tokoh tersebut merupakan wujud suatu hal yang lain. Meskipun tokoh dalam Jalan Lurus tidak memiliki identitas yang jelas, namun dapat dipahami bahwa mereka mewakili manusia-manusia yang teraleniasi, yakni manusia-manusia terbuang yang tidak dianggap keberadaanya. Mewakili sebuah kaum gelandangan atau kaum masyarakat kelas bawah.

Bentuk drama absurd dalam Jalan Lurus juga disajikan dengan tema-tema yang hadir atas kesadaran tokoh-tokoh dalam drama tersebut. Kesadaran tokoh-tokoh yang terasing ini yang menjadikan mereka mempertanyakan soal hidup dan membicarakan soal harapan. Persoalan makna hidup menjadi penting dalam Jalan Lurus. Ini terlihat dari tindakan para tokoh yang mencoba menjalani kehidupan yang absurd dengan harapan yang sama pada diri mereka. Kesadaran para tokoh ini hadir akibat keterasingan yang mereka miliki. Tanpa sebab yang tidak jelas, mereka tidak dapat memahami apa yang sebenarnya terjadi dan akhirnya begitu saja menjalani hidup dengan keabsurditasannya. Selain persoalan makna hidup, keterasingan, dan harapan, persoalan mengenai bunuh diri dan pemberontakan pun tak luput menjadi suatu persoalan bagi mereka. Namun, tema ini memang tidak terlalu dikedepankan. Hal ini karena tindakan para tokoh yang memilih jalan keluar dari yang absurd dengan jalan harapan dari pada memilih bunuh diri. Mengenai pemberontakan pun tidak banyak dimunculkan. Hanya beberapa adegan yang memang benar-benar dapat dikatakan sebagai bentuk pemberontakan, salah satunya yakni adegan dalam gua Kahfi dan akhir cerita naskah tersebut. Hal menarik yang menjadi temuan peneliti ialah tema-tema mengenai politik dan bahasa. Jalan Lurus menyajikan absurditas kehidupan dengan menyimbolkannya ke dalam dua pembicaraan tersebut. 
Selanjutnya yang membuktikan Jalan Lurus sebagai bentuk drama absurd ialah tekstur yang membangunnya. Dalam hal ini, dialog, suasana, dan spektakel menyajikan hal-hal yang menjadi khas dalam drama absurd. Sebagai bentuk drama, perhatian penelitian berpusat pada dialog. Dalam Jalan Lurus dialog-dialog yang dihadirkan merupakan sebuah bentuk kegagalan bahasa sebagai komunikasi. Seperti ciri absurd bahwa drama absurd dapat ditandai dengan gagalnya komunikasi yang dialami para tokohnya. Kegagalan komunikasi digambarkan dalam ketidakmengertian permasalahan yang dialami para tokoh yang hal ini menyebabkan perasaan terasing pada tokoh-tokoh Jalan Lurus. Dialog yang dalam hal ini petunjuk pemanggungan menunjukkan sebuah bahasa tubuh sama derajatnya dengan bahasa verbal yang digunakan sebagai alat komunikasi. Petunjuk teknis juga memberikan suasana absurd. Suasana ini hadir selain dalam dialog-dialog tokoh yang berfilsafat juga dihadirkan dalam petunjuk teknis yang menunjukkan keadaan statis dan terikat. Petunjuk tersebut memperlihatkan keterkaitan tokoh dengan setting tempat dan waktu yang tidak bergerak. Kesederhanaan artdirecting ini juga menunjukkan ciri khas drama absurd Indonesia. Selain itu, pengarang juga tidak membatasi panggung teater menjadi bentuk empat dimensi dinding. Wing atau tempat masuk dan keluarnya pemain tidak dibatasi hanya dari sisi kanan dan kiri, melainkan dari depan dan atas panggung. Dengan begitu, secara keseluruhan Jalan Lurus menyajikan sebuah spektakel kehidupan masyarakat Indonesia. Kehidupan manusia yang dijalani secara tidak sadar termasuk peristiwaperistiwa yang ada di Indonesia dihadirkan sebagai sebuah tontonan yang penuh gelak tawa sekaligus menyayat hati dan pikiran.

Keterkaitannya Jalan Lurus dengan pemikiran Albert Camus mengenai absurditas ialah pemikiran yang hampir sama antara Camus dengan pengarang Jalan 
Lurus. Berdasarkan analisis isi teks terhadap pemaknaannya dalam jagat filsafat absurditas ditemukan tema-tema mengenai makna hidup, keterasingan, bunuh diri, harapan, dan pemberontakan. Teks ini menunjukkan secara implisit dan eksplisit mengenai pemikiran-pemikiran tersebut.

Tema pertama yang juga sangat dominan ialah tema kesadaran filosofis. Analisis menunjukkan bahwa tindakan para tokoh disebabkan kehidupan mereka yang tidak memiliki makna. Ketiadaan makna ini dalam Jalan Lurus disebabkan karena ketidakbebasan tokoh dalam menentukan nasib, hal ini digambarkan dalam tokoh Lakon yang dapat memerankan apa saja. Peran-peran yang dimainkan oleh Lakon ternyata hanyalah perintah Bapak Atasan. Hal ini menunjukkan bahwa kehidupan manusia memang tidak akan bebas karena terikat oleh nasib. Nasib manusia telah diatur, setiap orang akan memainkan peranannya masing-masing. Perihal sebaliknya digambarkan oleh tokoh-tokoh serombongan lelaki. Serombongan lelaki sebagai bentuk simbol kaum gelandangan atau rakyat kalangan bawah yang menunjukkan bahwa mereka tidak memiliki makna hidup. Sebagai yang di bawah, hidup hanya dapat dinikmati bagi mereka yang di atas. Dengan begitu, serombongan lelaki yang sadar dengan absurditasnya ini memilih untuk mengambil harapan untuk menempuh absurditas dunia dan tidak pasrah begitu saja. Perihal kondisi dunia yang absurd digambarkan sebagai bentuk kehidupan modern. Modernitas memberikan dampak bagi kehidupan manusia. Hal ini menyebabkan mereka terlena oleh waktu dan begitu saja menjalani rutinitas kehidupan yang sama setiap harinya. Begitulah yang digambarkan Jalan Lurus dengan tindakan para tokoh yang terus berusaha memanjat tiang.

Tema selanjutnya menunjukkan keterasingan yang dialami tokoh-tokoh dalam Jalan Lurus. Keterasingan yang dialami tokoh Jalan Lurus menunjukkan perasaan 
terasing dari dunia dan kehidupan termasuk masyarakat. Konfrontasi antara manusia dengan dunia dialami oleh Lakon dan serombongan lelaki. Tokoh-tokoh tersebut terasing dari dunia manusia seutuhnya. Dunia yang mereka jalani bukanlah dunia manusia yang sesungguhnya. Hal ini menyebabkan mereka terlempar dan harus menjalani dunia yang penuh ketidakjelasan tersebut. Pengalaman terasing juga digambarkan melalui tindakan para tokoh yang diasingkan dalam sebuah gua. Mereka yang memasuki gua merupakan orang-orang yang diusir oleh masyarakat. Dengan begitu, di dalam gua yang gelap semakin menunjukkan keterasingan para tokoh yang mereka alami. Adanya pertentangan antara serombongan lelaki dan Lakon juga menunjukkan perasaan terasing yang dialami Lakon. Sepanjang cerita, Lakon tidak mempunyai lawan main secara khusus, hal ini yang menjadikan dia berbeda dan menjadikannya terasing. Kesadaran terasing pun muncul melalui pengalaman lelaki yang sadar akan pentas yang sedang mereka jalani. Terjadi pertentangan pemain dengan sutradara termasuk tim pentas atas peranan yang mereka jalani.

Tema selanjutnya yaitu mengenai bunuh diri dan pemberontakan. Kedua hal ini memang tidak terlalu banyak menjadi persoalan dalam Jalan Lurus. Kedua tindakan ini bukanlah sebuah bentuk tindakan yang sesungguhnya seperti dalam realitas kehidupan manusia menggantung dirinya pada seutas tali, menjatuhkan tubuhnya dari ketinggian atau memberontak dengan melakukan tindakan-tindakan anarkis yang merusak bendabenda di sekitarnya. Namun, tindakan-tindakan tersebut merupakan sebuah bentuk tindakan filosofis. Tindakan bunuh diri yang pertama ialah bentuk pengulangan sekaligus tindakan ketiadaan makna hidup bagi serombongan lelaki yang memanjat tiang. Mereka dengan sadar dan telah diingatkan bahwa pekerjaan yang mereka lakukan merupakan tindakan yang sia-sia. Hal ini menunjukkan adanya bunuh diri filosofis. 
Mereka menghiraukan apa saja demi mencapai apa yang mereka inginkan selama ini, yakni harapan yang tersimpul di atas tiang. Tindakan bunuh diri yang kedua ialah pengakuan yang dinyatakan oleh Lakon. Dengan sadar, Lakon menyatakan bahwa Bapak Atasan telah mati. Kematian Bapak Atasan ini mengisyaratkan kematian Lakon. Hal ini disebabkan setelah kematian Bapak Atasan, Lakon tidak lagi dapat berganti peran.

Mengenai pemberontakan, Jalan Lurus menyajikan kedua bentuk pemberontakan, yaitu historis dan metafisik. Pemberontakan historis dilakukan oleh sebagian lelaki yang berada dalam gua Kahfi. Pemberontakan tersebut terjadi akibat adanya penggusuran bagi mereka yang sedang berada dalam kegelapan. Ketidakdilan yang mereka alami menjadi penyebab mereka melakukan pemberontakan terhadap pembuatan jalan lurus. Kemudian, pemberontakan metafisik digambarkan melalui tindakan beberapa tokoh yang menolak mengakui kehidupan dunia dan berusaha menunjukkan eksistensinya. Bagi sebagian lelaki tersebut, mereka bukanlah tas yang selama ini menjadi harapan. Harapan sesungguhnya bukan berada pada orang lain. Harapan sejati hanya dapat direnungkan secara mendalam melalui pemikiran metafisika. Selain itu, penolakan terhadap kehidupan yang absurd juga ditampilkan. Sebagian lelaki menolak adanya homogen. Penolakan terhadap homogen ini artinya penolakan terhadap modernitas yang menghilangkan makna hidup. Dengan segala interpretasi di atas dapat ditentukan bahwa Jalan Lurus menyajikan bentuk pemikiran-pemikiran yang sama dengan Albert Camus mengenai absurditas dunia ditambah ciri drama absurd Indonesia yang dimiliki pengarang dalam bentuk idiom-idiom yang digunakan.

Bentuk drama absurd Indonesia dalam Jalan Lurus terlihat dari zaman kemunculan Jalan Lurus, idiom yang digunakan dan dari segi pengarangnya. Jalan 
Lurus muncul pada masa orde baru, jika dibaca oleh penikmat sastra Indonesia suasana tegang akan muncul karena pembaca akan teringat akan pengalaman masa lalu. Sebagai karya yang muncul pada tahun 1986, suasana tegang yang terjadi pada 1960-an dengan puncak tragedi 1965 , terasa masih membekas. Orde baru yang menciptakan suasana kebencian pada Partai Komunis Indonesia dan orang-orang komunis telah merangsang kecurigaan terhadap orang-orang yang tidak jelas identitasnya. Kelompok yang disebutsebut dalam Jalan Lurus memasuki gua Kahfi merupakan orang-orang yang tidak jelas identitasnya sebagaimana yang dimaksud sehingga menyebabkan mereka diasingkan. Tatkala bunyi ledakan pada awal adegan terdengar sangat keras, sangat wajar apabila pembaca atau penonton pentas ini menduga akan terjadi suatu hal yang genting yang menandakan akan datangnya bahaya yang akan mereka hadapi. Dengan begitu dapat dikatakan bahwa Jalan Lurus merupakan sebuah kritik terhadap sebuah rezim, yang menggunakan bahasa untuk melanggengkan kekuasaannya, yang memanipulasi bahasa demi membodoh-bodohi masyarakat, dan mengambil keuntungan dari sana. Inilah yang digambarkan dalam Jalan Lurus, manipulasi bahasa, logika bahasa Indonesia yang amburadul dan tumpang tindih dengan bahasa daerah, yang banyak mengandung homonim, homofon, dan homograf, yang membuat masyarakat tak bisa lagi membedakan antara representasi dan realitas.

Dalam Jalan Lurus ada adegan yang membicarakan perihal dukun dan kemenyan. Dukun merupakan seseorang yang dipercayai dapat mengobati, menolong orang sakit, dan memberi jampi-jampi. Dalam melaksanakan pekerjaannya, dukun membakar kemenyan sebagai suatu prasyarat dalam menjalakan ritual jampi-jampinya. Kedua hal tersebut merupakan budaya yang khas yang dapat ditemui di kampungkampung di Sumatera, Jawa, dan Bali. Selain itu yang terpenting ialah penggunaan 
idiom panjat pinang. Panjat pinang dalam Jalan Lurus tersebut tepatnya berasal dari suatu permainan rakyat Indonesia, yaitu permainan yang biasa digelar dan dimainkan umumnya oleh masyarakat Indonesia pada setiap perayaan ulang tahun kemerdekaan Indonesia. Sebagai suatu produk budaya, idiom panjat pinang itu artinya berasal dari kebudayaan Indonesia itu sendiri. Idiom lain yang digunakan ialah konsensus. Konsensus dianggap merupakan perwakilan dari wujud delegitimasi budaya setuju melalui hiperealitas demokrasi.

Jalan Lurus menyajikan suasana tak rasional khas wilayah pengarangnya. Hal ini menunjukkan perbedaan gaya absurditas barat dengan Indonesia yang dimiliki Jalan Lurus. Gaya absurd yang datang ke Indonesia diserap kemudian bercampur dengan unsur-unsur drama tradisi yang kemudian ramuan ini digunakan pengarang untuk menanggapi kondisi zaman di sekelilingnya. Sesuatu yang menunjukkan ciri absurd gaya pengarang Jalan Lurus ialah penggunaan bunyi-bunyian bahkan gerakan-gerakan akrobatik menjadi tumpuan drama Jalan Lurus, ditambah lagi dengan penggunaan beberapa kata yang disajikan menggunakan bahasa Minang seperti batangka, rangkayo, dan pepatah Minangkabau seperti sekali ale gadang, sekali tapianbarubahyang semakin menunjukkan sebuah bentuk drama absurd Indonesia yang khas dimiliki pengarang Jalan Lurus. Gaya lain yang dimiliki pengarang Jalan Lurus ialah pemikirannya dalam menghadapi absurditas. Melalui tindakan para tokohnya yang terasing, pengarang menjadikan para tokoh tersebut menjalani absurditas dengan memilih menjalaninya dengan harapan yang mereka miliki, berbeda dengan tindakan atas pemikiran Albert Camus yang seakan mengajak untuk melakukan tindakan bunuh diri dalam mengakhiri kehidupan yang absurd. Pengarang Jalan Lurus lebih menekankan bahwa hidup ini memiliki arti, meskipun masih terbatasnya hal tersebut atas takdir nasib yang ditentukan 
Tuhan. Arti makna hidup hanya dapat diraih jika manusia mau berusaha untuk keluar dari absurditas dengan menjalani hidup dengan harapan dan melakukan pemberontakan atau dalam hal ini membuat takdir atas kebebasan diri yang dapat ditentukan, seperti keinginan menjadi penguasa.

\section{KESIMPULAN}

Berdasarkan penelitian yang telah dilakukan, maka dapat disimpulkan bahwa naskah drama Jalan Lurus karangan Wisran Hadi merupakan sebuah bentuk naskah drama absurd. Bentuk drama absurd ini meliputi segi struktur dan tekstur. Dalam segi struktur ditemukan bentuk pembangunan yang absurd. Alur dalam Jalan Lurus menunjukkan sebuah peristiwa pengulangan kehidupan manusia. Tokoh-tokoh dalam Jalan Lurus merupakan tokoh absurd yang sadar dengan keabsurditasan dunia Adapun dalam segi tekstur yang membangun bentuk drama absurd berupa dialog yang menunjukkan ketidakmengertian dan kegagalan bahasa sebagai alat komunikasi. Selain itu, kesederhanaan setting yang dijelaskan pada petunjuk pemanggungan menjadi ciri drama absurd Indonesia. Selanjutnya, suasana yang disajikan dalam Jalan Lurus merupakan suasana ironi. Kelucuan dihadirkan bersamaan dengan ketiadaan makna hidup yang mendalam dan kegagalan manusia mencapai harapannya. Setelah pembacaan yang mendalam dan menyeluruh, maka pembaca dihadapkan dengan spektakel kehidupan absurd di Indonesia.

Tema-tema absurd dalam Jalan Lurus dapat diuraikan sebagai berikut. Makna hidup menjadi pembicaraan penting dalam tema absurditas. Ketiadaan makna hidup itulah inti masalah absurditas. Dalam Jalan Lurus ketiadaan makna hidup dialami oleh seluruh tokoh di dalamnya. Keterasingan dalam Jalan Lurus dihadirkan dalam 
kesadaran para tokoh menjadikan mereka terasing. Keterasingan dirasakan ketika para tokoh menyadari bahwa ini hanyalah sebuah pementasan. Bentuk keterasingan dihadirkan dalam bentuk keterasingan terhadap diri sendiri, masyarakat, dan dunia. Bunuh diri menjadi salah satu pilihan untuk keluar secara cepat dari absurditas dunia. Dalam Jalan Lurus tindakan bunuh diri tidak secara langsung disadari sebagai tindakan bunuh diri oleh tokoh-tokohnya. Harapan menjadi penting karena tindakan para tokoh di Jalan Lurus merupakan tindakan mengejar harapan. Di sinilah letak kesamaan pemikiran Albert Camus dengan pengarang Jalan Lurus. Pengarang meletakkan tokohtokohnya berada dalam dunia yang absurd, dengan posisi ketiadaan makna hidup disertai perasaan terasing. Pemberontakan paling banyak dilakukan oleh serombongan

Jalan Lurus merupakan sebuah bentuk drama absurd Indonesia dan memiliki tema-tema absurditas yang khas. Bentuk drama absurd Indonesia ini mengacu pada penggunaan unsur-unsur tradisi dan bahasa dari daerah pengarang yakni Minangkabau. Selain itu, Jalan Lurus juga merupakan sebuah bentuk kritik terhadap rezim orde baru yang disajikan dengan idiom panjat pinang dan manipulasi bahasa sebagai bentuk kekuasaan. Penggunaan bunyi-bunyian, gerakan akrobatik dalam panjat pinang, dan pepatah Minangkabau mencirikan gaya pengarang Jalan Lurus yang erat dengan tradisi. Gaya lain yang mencirikan drama absurd pengarang Jalan Lurus ialah pemikiran atas tindakan absurditas untuk memilih harapan sebagai jalan keluar dari absurditas dunia dibandingkan dengan melakukan tindakan bunuh diri.

\section{UCAPAN TERIMA KASIH}

Terima kasih kepada semua teman sejawat yang mendukung proses penelitian ini dapat berjalan lancar. 


\section{DAFTAR PUSTAKA}

Bagus, L. (2000). Kamus filsafat. Jakarta: Gramedia Pustaka Utama.

Camus, A. (1990). Krisis kebebasan. Jakarta: Yayasan Obor Indonesia.

Rowlands, M. (2004). Menikmati filsafat melalui film science fiction. Bandung: Mizan Pustaka.

Soemanto, B. (2007). Absurdisme dalam sastra Indonesia. Jakarta: Pusat Bahasa.

Wasono, S. (2007). Yang lucu dan yang absurd dalam lakon tahun 1970-an. Jakarta: Pusat Bahasa.

Yudiaryani. (2002). Panggung teater dunia. Yogyakarta: Pustaka Gondho Suli. 